\title{
DEVELOPMENT OF A RUBBING THRESHER FOR SOME SEED CROPS
}

\section{El-Shal, M.S. $^{1} \quad$ A.S., El-Ashry ${ }^{2} \quad$ A.M., El-Shal ${ }^{3} \quad$ W.B., Fakhrany ${ }^{4}$}

\section{ABSTRACT}

A rubbing thresher was developed and evaluated on threshing some seed crops as flax and sunflower. The performance of the developed machine was tested in two independent experiments according to the kind of crop by studying some engineering factors that affecting threshing operation such as threshing drum speed, threshing belt speed, and concave clearance. The flax experiment was performed by testing the drum speed at 4.2, 5.5, 6.4, and $7.3 \mathrm{~m} / \mathrm{s}$, threshing belt speed at 0.42, 0.67, 0.96, and $1.25 \mathrm{~m} / \mathrm{s}$, and concave clearance at $1.5,2.5$, and $4.0 \mathrm{~cm}$. In addition, the sunflower experiment was performed at the same levels of drum speed and belt speed addition to other three levels of concave clearance of 2.5, 4.0 , and $5.5 \mathrm{~cm}$. The results showed that, the drum speed of $7.3 \mathrm{~m} / \mathrm{s}$, belt speed of $0.42 \mathrm{~m} / \mathrm{s}$, and concave clearance of $1.5 \mathrm{~cm}$ were the optimum conditions for threshing flax crop by the developed thresher. In addition, the optimum conditions for threshing sunflower by the rubbing thresher were $7.3 \mathrm{~m} / \mathrm{s}, 0.42 \mathrm{~m} / \mathrm{s}$, and $2.5 \mathrm{~cm}$ of drum speed, belt speed, and concave clearance respectively.

Key words: Rubbing thresher, flax threshing, sunflower threshing

\section{INTRODUCTION}

Whreshing is an ancient process used to separate seeds from the capsules, pods, panicles... etc, it is the important practice which

can affect the quantitative and qualitative of any yield, through affecting the percent of seed damage and seed losses. One of the biggest constraints for increasing the production area of seed crops like flax and sunflower in Egypt has been the lack of suitable threshing machine.

\footnotetext{
${ }^{1}$ Prof. Emeritus of Agric. Eng., Fac. of Agric., Zagazig University ${ }^{2}$ Head of Research, Agric. Eng. Inst., Agric. Res. Center ${ }^{3}$ Assistant Prof. of Agric. Eng., Fac. of Agric., Zagazig University ${ }^{4}$ Assistant Researcher in Agric. Eng. Inst., Agric. Res. Center
} 
Bainer et al. (1982) stated that flax crop can be threshed by using one rubber covered roll and one steel roll. The upper roll is spring-loaded and driven about 10 percent faster than the lower roll to give a rubbing action in addition to the squeezing effect.

Adjustable stops on the spring-loaded roll are set to provide a minimum clearance sufficient for the passage of seeds without damage. Klenin et al. (1985) stated that the effectiveness of bond rupture and plant deformation depends upon the mode of action of threshing of the plants. The search for an optimal mode of action to break this plant is one of the most important aspects of the theory of the threshing equipment can be developed. Schild et al. (1991) showed that with respect to sunflower threshing, the cylinder speed must be slow enough to avoid cracking the seed, approximately $300 \mathrm{rpm}$. The concave must be open enough to avoid grinding up the head. Mesquita and Hanna (1993) concluded that the rubbing device had a high threshing efficiency. The threshing efficiency was greater than $93 \%$ when the soybean pods moisture content was $10 \%$ w.b. and belt speed ranged from 10.8 to $13.4 \mathrm{~km} / \mathrm{h}$. Khater (2000) concluded that the optimum working condition of the tested corn sheller machine, used for sunflower threshing occurred at $7.2 \mathrm{~m} / \mathrm{s}$ drum speed, $14 \%$ seed moisture content and $4.0 \mathrm{~cm}$ concave clearance. The criterion cost of the tested machine working in optimum condition was 280 L.E. /fed. Sudajan et al. (2002) mentioned that the effect of drum speed was the most significant on power requirement, followed by feed rate and drum type. The type of drum affected specific energy consumption most significantly, followed by drum speed and feed rate. It was observed that the power requirement of the threshing unit increased as the speed of threshing drum was increased. EL-Ashry et al. (2006) reported that, the tractor treading (trampling by tractor wheel) is still the common practice for threshing flax crop. They added that, to obtain high fiber percentage and low losses (less unthreshed capsules and less total straw damage) the following conditions are recommended for the tractor during threshing flax crop by trampling inflation pressure $120 \mathrm{kpa}$, tractor forward speed 
$4.17 \mathrm{~km} / \mathrm{h}$. El-Ashry (2011) constructed and tested a flax rubbing thresher consists mainly of four pairs of steel rollers, each lower roll is held against the upper roll by spring pressure which can be regulated, the lower rollers were adjusted to move slower than the upper rollers to provide the rubbing action. The thresher was tested at different revolving speeds for upper and lower rollers severally. He found that increasing the upper rollers speed increased the percentage of stalk losses and threshing efficiency, versa was occurred with increasing the lower rollers. Also increasing the revolving speed for the upper and lower rollers severally leads to increase the thresher output.

The prevalent threshing method of flax crop of trampling stalks under tractor tires is more laborious, more tedious, consuming more time, and causing more stalks damage. Also no specialized threshing machine for sunflower crop, it more times threshed by the familiar Turkish threshing machine which depends upon the impact and shear forces which causing more damage for the sunflower seeds, in addition to the fleshy material of the head causing more problems with the mentioned machine.

In order to increase the production of flax, sunflower, and other seed crops, the development of a rubbing thresher has therefore become important. Therefore, the main objectives of the present study were the following:-

1-To modify and improve a rubbing thresher suiting for seed crops and applying the theory of frictional rubbing force

2-To study the engineering factors of the threshing machine, affecting threshing efficiency and energy required

3-To evaluate the performance of the modified threshing machine from the technological and economical points of view

\section{MATERIALS AND METHODS}

The main objective of this study is to develop and modify a rubbing threshing machine to suit threshing of some seed crops as flax and sunflower. Constructing and testing of the developed machine was 
carried out at the workshop of El-Gemeza Agricultural Research Station, El-Gharbia Governorate.

\section{1- The threshing machine before modifying:}

The threshing machine used in this study had used to thresh some legume crops as lentil and chickpea depending upon the rubbing theory by two rubber drums have the same diameter of $350 \mathrm{~mm}$. The drums were assembled one beneath the other and rotates toward each other (oncoming rotation) with different angular velocities to produce the rubbing action. This mechanism was not sufficient to carry out the threshing operation, because, the threshing zone in that threshing mechanism was the tangential line between the two drums, also the mentioned mechanism didn't fit to thresh the flax crop.

\section{2- The threshing machine after modifying:}

The developed threshing machine (Figures $1 \& 2$ ) consists of a rubber threshing drum $350 \mathrm{~mm}$ in diameter, a rubber belt of $510 \mathrm{~mm}$ in width; and $4.0 \mathrm{~mm}$ in thickness rotates around three rollers of $80 \mathrm{~mm}$ in diameter, a transmission system consists of a sprocket chain and two gears rotate beneath a guide of a curved steel rod of $14 \mathrm{~mm}$ diameter, cleaning system includes a shaker and fan, the source of power was electric motor of $10 \mathrm{Hp}(7.46 \mathrm{~kW})$ with a rotating speed of $970 \mathrm{rpm}$ and a potential difference (voltage) $380 \mathrm{v}$.

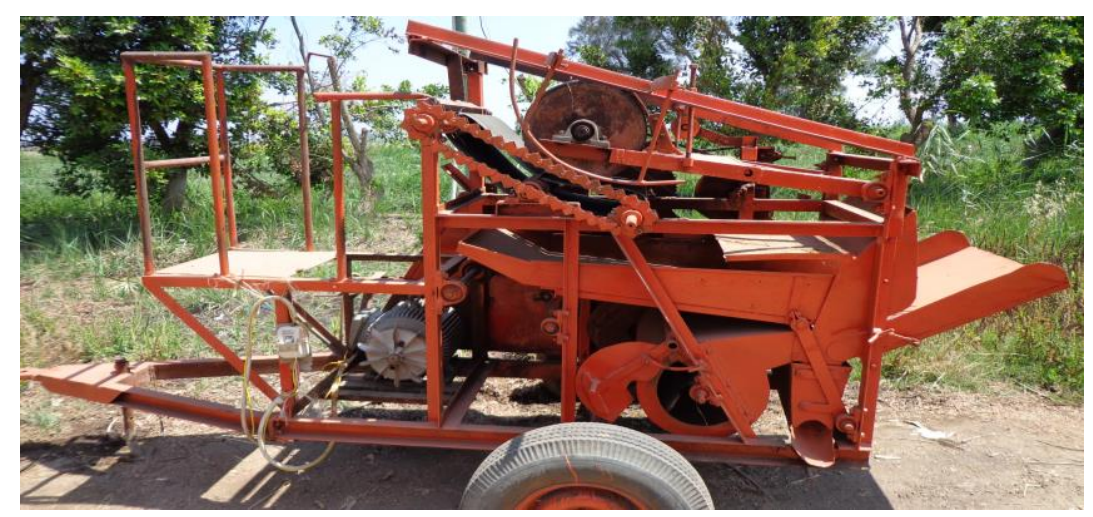

Fig. (1): The threshing machine after modifying 
FARM MACHINERY AND POWER
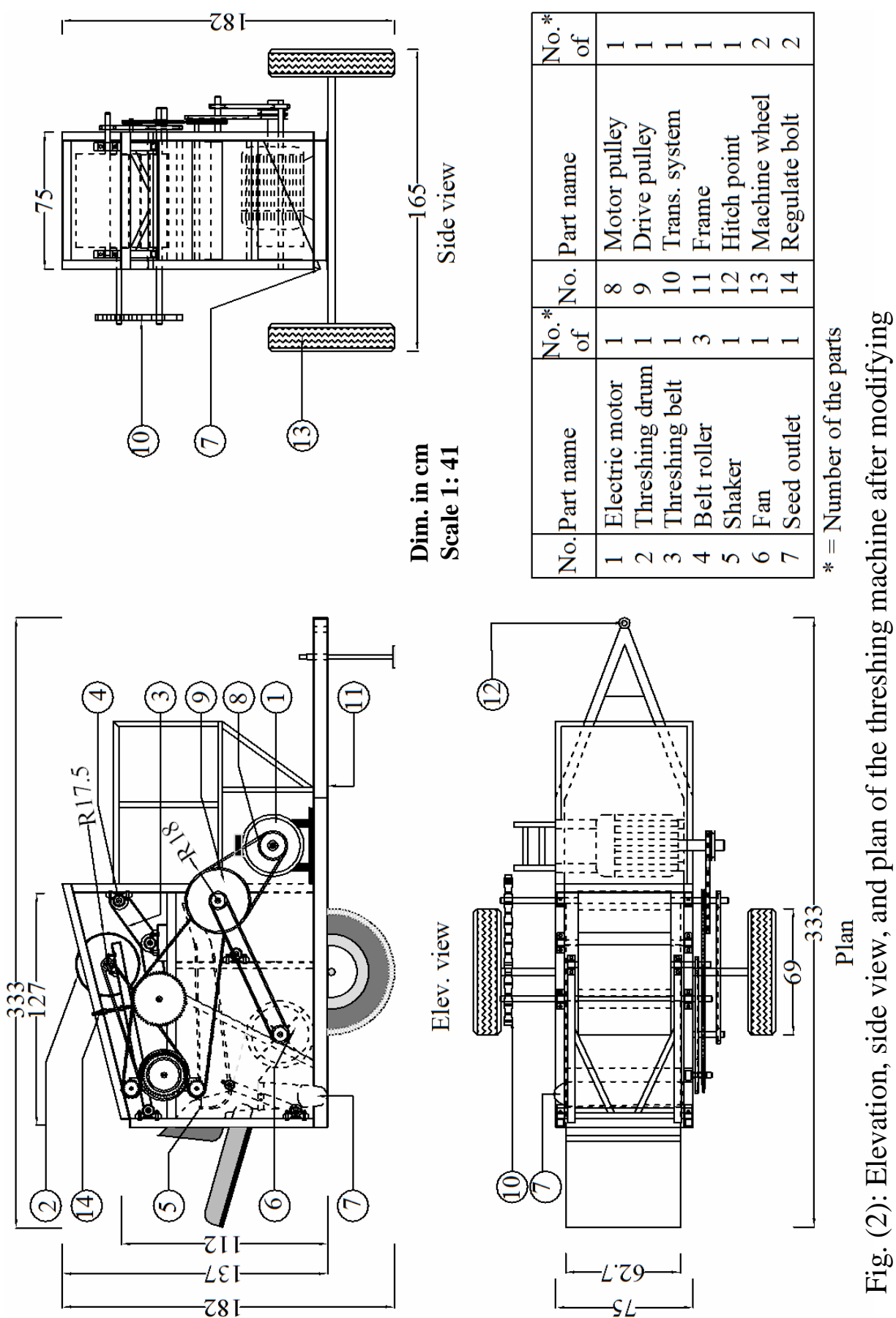


\section{3- The Used Crops:}

The evaluating of the developed machine was carried out with two crops, flax and sunflower, (Table 1) shows their measured physical properties and specifications.

Table (1): The measured physical properties and specifications for flax and sunflower crops

\begin{tabular}{|c|c|c|c|}
\hline \multicolumn{2}{|c|}{ Flax (Sakha 1) } & \multicolumn{2}{|c|}{ Sunflower (Sakha 53) } \\
\hline $\begin{array}{l}\text { The technical } \\
\text { characteristic }\end{array}$ & $\begin{array}{l}\text { Mean } \\
\text { value }\end{array}$ & $\begin{array}{l}\text { The technical } \\
\text { characteristic }\end{array}$ & $\begin{array}{l}\text { Mean } \\
\text { value }\end{array}$ \\
\hline Plant height, $\mathrm{cm}$ & 101.5 & Plant height, $\mathrm{cm}$ & 123.5 \\
\hline Technical length, cm & 82.45 & Head diameter, $\mathrm{cm}$ & 22.76 \\
\hline Stem diameter, $\mathrm{mm}$ & 1.75 & Stem diameter, $\mathrm{cm}$ & 2.61 \\
\hline No. of capsules/plant & 11.5 & No. of seeds/head & 365.2 \\
\hline Capsule diameter, $\mathrm{cm}$ & 0.78 & Seed yield, kg/fed. & 820 \\
\hline Seed yield, kg/fed. & 600 & Mass of 1000 seeds, $\mathrm{g}$ & 58.4 \\
\hline Mass of 1000 seeds, $g$ & 9.5 & Seed length, $\mathrm{cm}$ & 1.087 \\
\hline Seed length, cm & 0.547 & Seed width, $\mathrm{cm}$ & 0.632 \\
\hline Seed width, cm & 0.261 & Seed thickness & 0.426 \\
\hline Seed thickness & 0.103 & Sphericity, \% & 61.08 \\
\hline Sphericity, \% & 44.79 & & \\
\hline Stalk yield, $\mathrm{Mg} / \mathrm{fed}$. & 3.5 & & \\
\hline
\end{tabular}

\section{4- Experiment Procedure :}

The developed machine was evaluated in two independent experiments based on the kind of the threshed crop. The first experiment was specialized to flax crop, where the second one was specialized to sunflower crop.

The developed machine was evaluated at different factors affecting the threshing operation such as the following:

1. Drum peripheral speed at four different levels of about 4.2, 5.5, 6.4, and $7.3 \mathrm{~m} / \mathrm{s}$,

2. Belt peripheral speed at four different levels of about $0.42,0.67,0.96$, and $1.25 \mathrm{~m} / \mathrm{s}$, 
3. Concave clearance at three levels of $1.5,2.5$, and $4.0 \mathrm{~cm}$ for flax; and other three levels of $2.5,4.0$, and $5.5 \mathrm{~cm}$ for sunflower.

The two crops were dried naturally, and the threshing operation was carried out when the moisture content of the crops were stabilized at $11.38 \%$ \& $10.51 \%$ w.b for flax and sunflower respectively.

\section{5- Experimental Measurements:}

\section{Seed-stalk ratio of flax:}

The seed-stalk ratio was calculated by the following formula:-

$$
\mathrm{SSt}_{\mathrm{R}}=\frac{\mathrm{S}_{\mathrm{w}}}{\mathrm{St}_{\mathrm{w}}} \times 100
$$

Where:-

$\mathrm{SSt}_{\mathrm{R}}=$ seed-stalk ratio; $\%$

$\mathrm{St}_{\mathrm{w}} \quad=$ stalk mass; $\mathrm{g}$

$\mathrm{S}_{\mathrm{w}} \quad=$ seed mass; $\mathrm{g}$

\section{Threshing efficiency:}

The threshing efficiency was cal culated from the following expression:

$$
\mathrm{Th}_{\mathrm{e}}=\frac{\mathrm{S}_{\text {outlet }}}{\mathrm{Ut}_{\mathrm{w}}+\mathrm{S}_{\text {outlet }}} \times 100
$$

Where:-

$\mathrm{Th}_{\mathrm{e}} \quad=$ threshing efficiency for both crops; $\%$

$\mathrm{S}_{\text {outlet }}=$ mass of threshed seeds at the main seed outlet; $\mathrm{g}$

$\mathrm{Ut}_{\mathrm{w}} \quad=$ unthreshed seed mass; $\mathrm{g}$

\section{Flax stalk losses:}

Flax stalk losses are the stalks that damaged and lost during threshing operation, which can be determined by the following expression:

$$
\mathrm{S}_{\mathrm{L}}=\frac{\mathrm{S} \cdot \mathrm{w}_{\mathrm{a}}}{\mathrm{S} \cdot \mathrm{w}_{\mathrm{b}}} \times 100
$$

Where:

$\mathrm{S}_{\mathrm{L}} \quad=$ percent of stalk losses

S. $\mathrm{w}_{\mathrm{b}}=$ estimated mass of flax stalks before threshing operation; $\mathrm{g}$

S. $\mathrm{w}_{\mathrm{a}}=$ measured mass of flax stalks after threshing operation, $\mathrm{g}$.

\section{Visible seed damage:}

The percentage of the seed damage was determined by the following formula: 


$$
\mathrm{D}=\frac{\mathrm{d}}{\mathrm{t}} \times 100
$$

Where:

$\mathrm{D}=$ percent of seed damage

$\mathrm{d}=$ amount of seed damage, $\mathrm{g}$

$\mathrm{t}=$ total mass of the sample, $\mathrm{g}$

\section{Invisible seed damage:}

In order to estimate the invisible seed damage, the germination test was carried out for each treatment, then the germination ratio was estimated for each treatment and compared with the germination ratio of the seeds, which separated manually to determine the invisible seed damage as following:-

$$
\text { Invisible seed damage, } \%=\frac{\text { g. } r_{\mathrm{t}}}{\mathrm{g} \cdot \mathrm{r}_{\mathrm{m}}} \times 100
$$

Where:

g. $\mathrm{r}_{\mathrm{t}}=$ germination ratio of each treatment, $\%$

g. $\mathrm{r}_{\mathrm{m}}=$ germination ratio of the seeds which separated manually, $\%$

\section{Threshing machine productivity:}

The threshing machine productivity per $\mathrm{Mg} / \mathrm{h}$ was calculated from the following expressions:-

Flax threshing productivity $(\mathrm{Mg} / \mathrm{h})=\frac{\left(\mathrm{S}_{\mathrm{w}}+\mathrm{k}_{\mathrm{w}}\right) \times 3.6}{\mathrm{~T}}$

Sunflower threshing productivity $(\mathrm{Mg} / \mathrm{h})=\frac{\mathrm{S}_{\mathrm{w}} \times 3.6}{\mathrm{~T}}$

Where:

$\mathrm{S}_{\mathrm{w}}=$ output seeds of both crops in each treatment; $\mathrm{kg}$,

$\mathrm{k}_{\mathrm{W}}=$ output stalks of flax crop in each treatment; $\mathrm{kg}$,

$\mathrm{T}=$ time of treatment; $\mathrm{s}$.

\section{Power and energy requirements:}

The consumed power was estimated using the measurement of line current in Amperes and potential difference in volts. The actual power of 
the machine $(\mathrm{P})$ was estimated according to the following equation (Lockwood and Dunstan, 1971):

$$
\mathrm{p}=\frac{\sqrt{3} \cdot \mathrm{I} \cdot \mathrm{V} \cdot \eta \cdot \cos \theta}{1000}
$$

Where:

$\mathrm{P} \quad=$ total consumed power; $\mathrm{kW}$,

I = line current strength in amperes,

$\mathrm{V}=$ potential difference (voltage ); equal to $380 \mathrm{v}$,

$\eta \quad=$ mechanical efficiency; assumed $(95 \%)$,

$\cos \theta=$ power factor (was taken as $85 \%$ ),

$\sqrt{3}=$ coefficient current three phase.

The specific energy requirement (kW.h/Mg) was calculated by dividing the consumed power $(\mathrm{kW})$ by the threshing productivity $(\mathrm{Mg} / \mathrm{h})$.

\section{Operational cost:}

Machine operating cost was calculated using the well known procedure of (Kepner et al., 1982).

\section{Criterion cost:}

The criterion cost of each treatment include the total cost $\mathrm{LE} / \mathrm{Mg}$, the price of the lost seeds for both crops LE/Mg, and the price of the lost flax stalks.

\section{RESULTS AND DISCUSSION}

\section{1- Threshing Efficiency:}

Figures 3 \& 4 showed that, increasing drum speed increased the threshing efficiency of flax and sunflower crops at all belt speeds and concave clearances. When the drum speed increased from 4.2 to $7.3 \mathrm{~m} / \mathrm{s}$, the threshing efficiency of flax increased from 91.69 to $98.08 \%$ at belt speed of $0.42 \mathrm{~m} / \mathrm{s}$, and concave clearance of $1.5 \mathrm{~cm}$. In addition, the threshing efficiency of sunflower increased from 92.78 to $99.51 \%$ by increasing the drum speed from 4.2 to $7.3 \mathrm{~m} / \mathrm{s}$ at belt speed of $0.42 \mathrm{~m} / \mathrm{s}$, and concave clearance of $2.5 \mathrm{~cm}$. This is because of increasing drum 
speed causes more rubbing action at the capsules or the heads, which led to more separating of the seed and more threshing efficiency, especially with the lowest belt speed.

Figures $3 \& 4$ showed also that, the threshing efficiency was decreased by increasing the belt speed at all drum speeds and concave clearances, as by increasing the belt speed from 0.42 to $1.25 \mathrm{~m} / \mathrm{s}$, the threshing efficiency of flax crop decreased from 95.75 to $89.55 \%$ at $7.3 \mathrm{~m} / \mathrm{s}$ of drum speed, and $2.5 \mathrm{~cm}$ of concave clearance.

Likewise, the threshing efficiency of sunflower decreased from 96.74 to $94.46 \%$, at $7.3 \mathrm{~m} / \mathrm{s}$ of drum speed, and $4.0 \mathrm{~cm}$ of concave clearance. This is because decreasing the belt speeds means increasing the threshing period, consequently increasing the rubbing action, and increasing the threshing efficiency.

Also figures $3 \& 4$ showed that Increasing the concave clearance decreased the threshing efficiency for flax and sunflower crops at all drum speeds, and belt speeds. The threshing efficiency of flax crop was $93.31 \%$ and decreased to $86.74 \%$ by increasing the concave clearance from 1.5 to $4.0 \mathrm{~cm}$ at drum speed of $7.3 \mathrm{~m} / \mathrm{s}$, and belt speed of $1.25 \mathrm{~m} / \mathrm{s}$. As well as, increasing the concave clearance from 2.5 to $5.5 \mathrm{~cm}$ with sunflower crop tends to decrease the threshing efficiency from $96.59 \%$ to $92.21 \%$ at $7.3 \mathrm{~m} / \mathrm{s}$ of drum speed, and $1.25 \mathrm{~m} / \mathrm{s}$ of belt speed. This is because of increasing the concave clearance allows the passage of a large amount of the crop with less exposing to the threshing drum. Therefore, the threshing losses increased and threshing efficiency decreased, by increasing the concave clearance.

The highest values of threshing efficiency of flax and sunflower respectively were $98.08 \& 99.51 \%$, which obtained at drum speed of 7.3 $\mathrm{m} / \mathrm{s}$, belt speed of $0.42 \mathrm{~m} / \mathrm{s}$, and concave clearances of $1.5 \& 2.5 \mathrm{~cm}$. Whereas, the lowest values were $78.85 \& 84.73 \%$, which obtained at drum speed of $4.2 \mathrm{~m} / \mathrm{s}$, belt speed of $1.25 \mathrm{~m} / \mathrm{s}$, concave clearances of 4.0 $\& 5.5 \mathrm{~cm}$ for flax and sunflower respectively. 

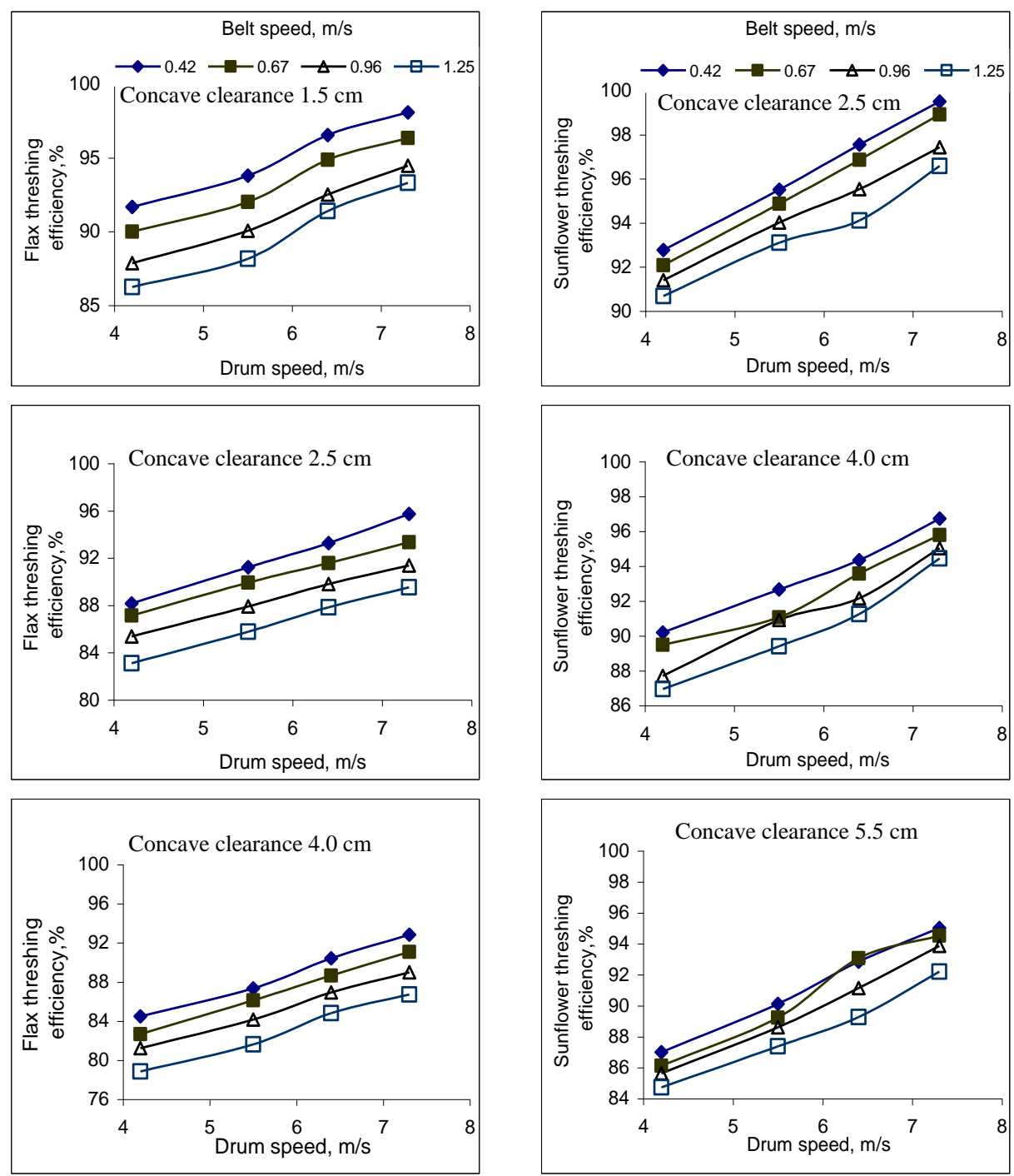

Fig. (3): Effect of drum speed, belt speed, and concave clearance on flax threshing efficiency.

Fig. (4): Effect of drum speed, belt speed, and concave clearance on sunflower threshing efficiency.

\section{2- Flax Stalk Losses:}

Fig. 5 showed that, the flax stalk losses would be increased, if the drum speed increased. By increasing the drum speed from 4.2 to $7.3 \mathrm{~m} / \mathrm{s}$, the stalk losses percent increased from 3.18 to 4.12 at belt speed of $0.42 \mathrm{~m} / \mathrm{s}$, 
and concave clearance of $1.5 \mathrm{~cm}$. this is due to increase the rubbing action on the crop.

Also it clarified that the peripheral belt speed has an inverse correlation with the flax stalk losses. Increasing the belt speed from 0.42 to $1.25 \mathrm{~m} / \mathrm{s}$ decreased the flax stalk losses from 4.12 to $2.81 \%$ at drum speed of 7.3 $\mathrm{m} / \mathrm{s}$, and concave clearance of $1.5 \mathrm{~cm}$. The reason of that is the threshing period, by increasing the pelt speed, the threshing period was decreased, consequently the flax stalk exposed to the threshing drum less time compared with the lowest value of the belt speed.

The data mentioned in Fig. 5 showed also that, the flax stalk losses tend to decrease by increasing the concave clearance at all drum speeds, and belt speeds. By increasing the concave clearance from 1.5 to $4.0 \mathrm{~cm}$, the flax stalk losses decreased from 4.12 to $3.48 \%$ at $7.3 \mathrm{~m} / \mathrm{s}$ of drum speed, and $0.42 \mathrm{~m} / \mathrm{s}$ of belt speed. Decreasing stalk losses by increasing the concave clearance due to the large space between the threshing drum and the belt, which allows the passage of a large amount of crop with less exposing to the threshing drum, therefore the stalk losses decreased.

The highest value of stalk losses of $4.12 \%$ was obtained at $7.3 \mathrm{~m} / \mathrm{s}, 0.42$ $\mathrm{m} / \mathrm{s}$, and $1.5 \mathrm{~cm}$ of drum speed, belt speed, and concave clearance respectively. Whereas the lowest value of $1.48 \%$ was obtained at drum speed of $4.2 \mathrm{~m} / \mathrm{s}$, belt speed of $1.25 \mathrm{~m} / \mathrm{s}$, and concave clearance of $4.0 \mathrm{~cm}$.

\section{3- Visible and Invisible Seed Damage:}

With regard to seed damage of flax crop, it was observed that neither visible nor invisible seed damage was occurred at all drum speeds, belt speeds, and concave clearances. This is because the flax seeds are strong with a smooth surface and small size.

In addition, no invisible seed damage was remarked with sunflower seeds by the germination test at all drum speeds, belt speeds, and concave clearances. This is due to the black color of the seed, which helps to note the smallest details of the seed surface. In addition to all the damage has occurred in the seed base not on the sides because of the effect of friction. 
From Fig. 6 it can be noticed that, the visible seed damage of sunflower tends to increase by increasing drum speed. Increasing the drum speed from 4.2 to $7.3 \mathrm{~m} / \mathrm{s}$ led to increase the damaged seed of sunflower from 0.20 to $0.66 \%$ at belt speed of $0.42 \mathrm{~m} / \mathrm{s}$, and concave clearance of $2.5 \mathrm{~cm}$. This is due to increase the rubbing action with increasing the drum speed, which leads to more force on the seeds.

Fig. 6 illustrates also that, the belt speed related inversely with the sunflower seed damage. The obtained results clarified that increasing the belt speed from 0.42 to $1.25 \mathrm{~m} / \mathrm{s}$ decreased the sunflower seed damage from 0.66 to $0.27 \%$ at $7.3 \mathrm{~m} / \mathrm{s}$ of drum speed, and $2.5 \mathrm{~cm}$ of concave clearance. Decreasing the belt speed leads to increase threshing period, which makes the heads exposed to the threshing drum more times, consequently the probability of seed broken will be increased comparing with the small threshing period and belt speed.

The data presented in Fig. 6 showed also that, the seed damage of sunflower decreased by increasing the concave clearance between the threshing drum and the threshing belt at all drum speeds, and all belt speeds. The obtained data indicated that increasing the concave clearance from 2.5 to $5.5 \mathrm{~cm}$ led to decrease the seed damage by 50.0, 45.71, 42.86, and $37.88 \%$ at drum speed of $4.2,5.5,6.4$, and $7.3 \mathrm{~m} / \mathrm{s}$ respectively, and belt speed of $0.42 \mathrm{~m} / \mathrm{s}$. This is because of the wide concave clearance allows the passage of a large amount of the heads with less pressure by the threshing drum.

The highest and the lowest values of sunflower seed damage of $0.66 \&$ $0.05 \%$ were obtained at $7.3 \& 4.2 \mathrm{~m} / \mathrm{s}$ of drum speed, $0.42 \& 1.25 \mathrm{~m} / \mathrm{s}$ of belt speed, as well as $2.5 \& 5.5 \mathrm{~cm}$ of concave clearance respectively.

\section{4- Threshing Machine Productivity:}

The data in figures $7 \& 8$ show the productivity of the threshing machine by $\mathrm{Mg} / \mathrm{h}$ at the different levels of drum speed, belt speed, and concave clearance for flax and sunflower crops respectively.

The obtained data indicated that, a positive proportion was noticed between the drum speed and the threshing machine productivity during threshing flax and sunflower crops. Increasing the drum speed from 4.2 to $7.3 \mathrm{~m} / \mathrm{s}$ increased the threshing machine productivity of flax crop from 0.392 to $0.486 \mathrm{Mg} / \mathrm{h}$ at $0.42 \mathrm{~m} / \mathrm{s}$ of belt speed, and $1.5 \mathrm{~cm}$ 

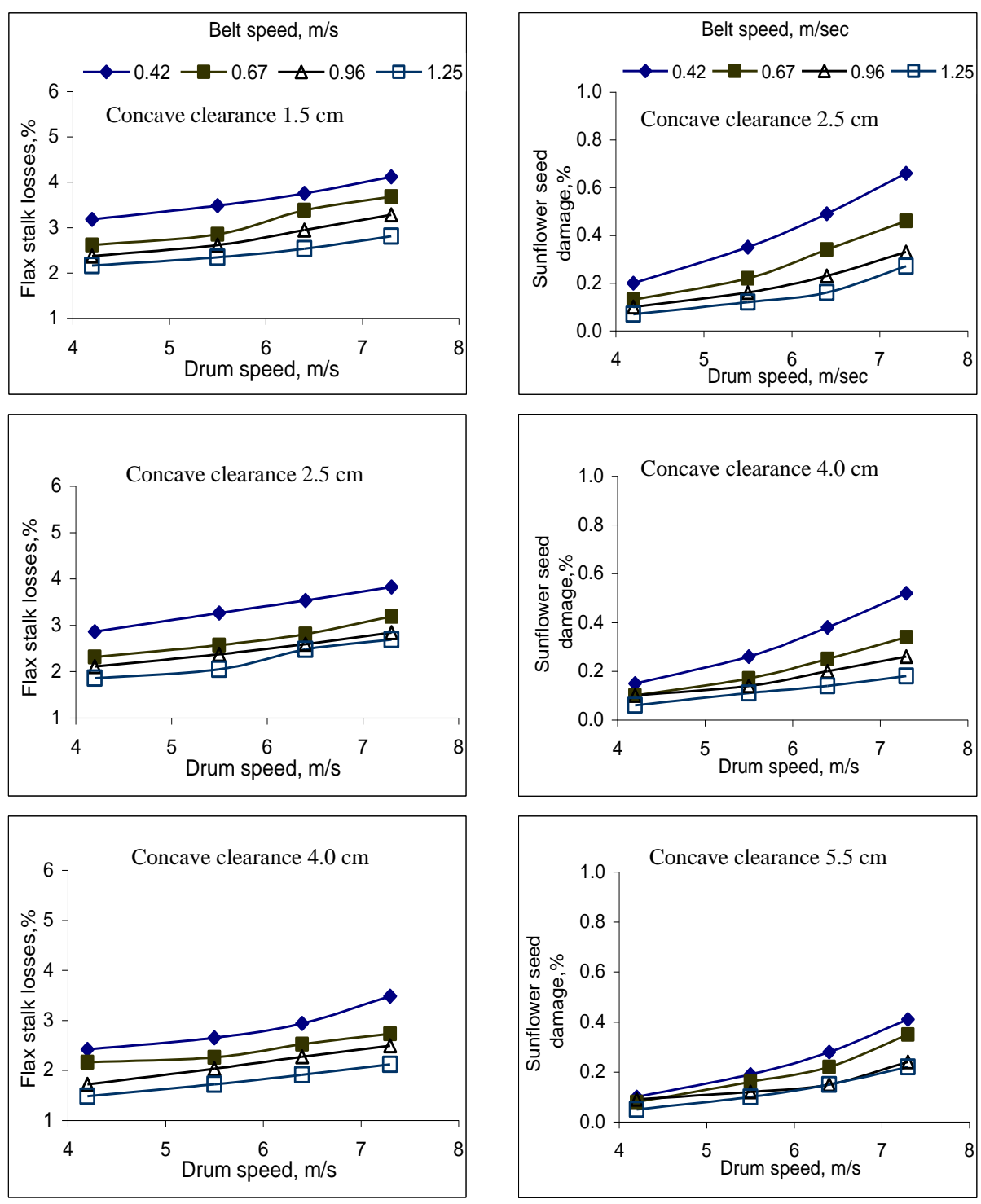

Fig. (5): Effect of drum speed, belt speed, and concave clearance on flax stalk losses.

Fig. (6): Effect of drum speed, belt speed, and concave clearance on sunflower seed damage.

of concave clearance. In addition, the machine productivity of sunflower increased from 0.319 to $0.371 \mathrm{Mg} / \mathrm{h}$ by increasing the drum speed from 4.2 to $7.3 \mathrm{~m} / \mathrm{s}$, at $0.42 \mathrm{~m} / \mathrm{s}$ of belt speed, and $2.5 \mathrm{~cm}$ of concave clearance. This is because of increasing the drum speed causes more speed for the crop between the drum and the belt comparing with the low 
speed of the threshing drum, for that reason, the productivity of the threshing machine increased with increasing the drum speed.

Figures $7 \& 8$ illustrate also that, increasing the belt speed increased the threshing machine productivity for flax and sunflower crops at all drum speeds, and concave clearances. Increasing the belt speed from 0.42 to $1.25 \mathrm{~m} / \mathrm{s}$ increased the machine productivity with flax from 0.486 to $0.598 \mathrm{Mg} / \mathrm{h}$, at drum speed of $7.3 \mathrm{~m} / \mathrm{s}$, and concave clearance of $1.5 \mathrm{~cm}$. The same trend has occurred with sunflower, as the threshing machine productivity increased from 0.371 to $0.387 \mathrm{Mg} / \mathrm{h}$, by increasing the belt speed from 0.42 to $1.25 \mathrm{~m} / \mathrm{s}$ at drum speed of $7.3 \mathrm{~m} / \mathrm{s}$, and concave clearance of $2.5 \mathrm{~cm}$. This is due to increase the speed of the threshed materials under the threshing drum, consequently increasing the feeding rate and the productivity of the threshing machine.

With regard to concave clearance, the obtained data referred to the threshing machine productivity was increased by increasing the concave clearance for flax and sunflower at all drum speeds, and belt speeds.

Increasing the concave clearance from 1.5 to $4.0 \mathrm{~cm}$ in case of flax threshing increased the productivity of the thresher from 0.486 to 0.640 $\mathrm{Mg} / \mathrm{h}$ at belt speed of $0.42 \mathrm{~m} / \mathrm{s}$, and drum speed of $7.3 \mathrm{~m} / \mathrm{s}$. Whereas, the thresher productivity of sunflower increased from 0.371 to $0.446 \mathrm{Mg} / \mathrm{h}$ by increasing the concave clearance from 2.5 to $5.5 \mathrm{~cm}$ at belt speed of $0.42 \mathrm{~m} / \mathrm{s}$, and drum speed of $7.3 \mathrm{~m} / \mathrm{s}$. Increment the productivity of the threshing machine by increasing the concave clearance due to increase the passage of the threshed materials between the threshing drum and the belt in the time unit.

The highest and the lowest values of the threshing machine productivity of flax crop of $0.783 \& 0.392 \mathrm{Mg} / \mathrm{h}$ were obtained at drum speed of 7.3 $\& 4.2 \mathrm{~m} / \mathrm{s}$, belt speed of $1.25 \& 0.42 \mathrm{~m} / \mathrm{s}$, and concave clearance of $4.0 \&$ $1.5 \mathrm{~cm}$ respectively. Whereas the highest and the lowest values of the threshing machine productivity of sunflower crop of $0.459 \& 0.319 \mathrm{Mg} / \mathrm{h}$ were obtained at drum speed of $7.3 \& 4.2 \mathrm{~m} / \mathrm{s}$, belt speed of $1.25 \& 0.42$ $\mathrm{m} / \mathrm{s}$, and concave clearance of $5.5 \& 2.5 \mathrm{~cm}$ respectively. 

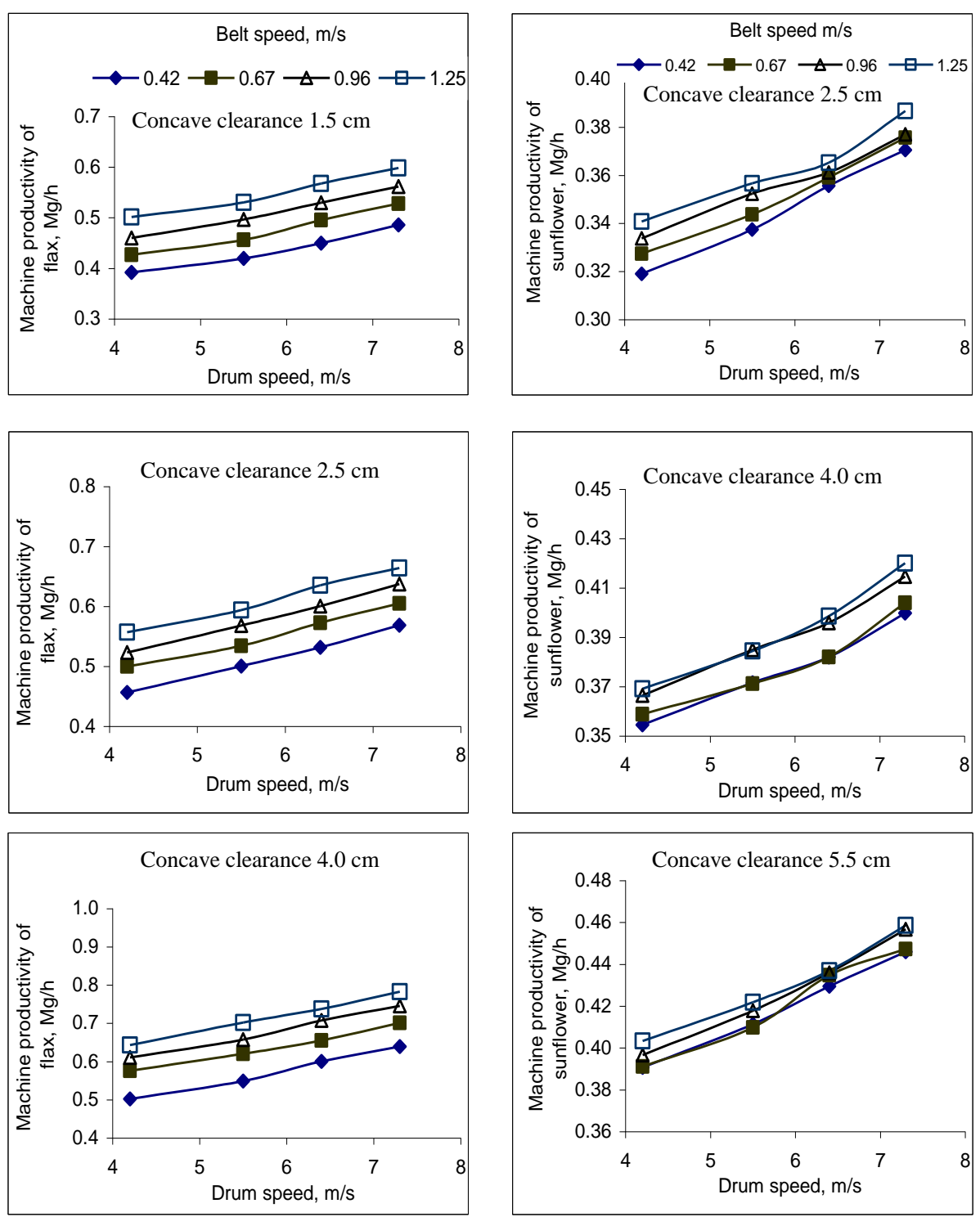

Fig. (7): Effect of drum speed, belt speed, and concave clearance on the machine productivity of flax.

Fig. (8): Effect of drum speed, belt speed, and concave clearance on the machine productivity of sunflower.

\section{5- Power and Energy Requirements:}

Tables $2 \& 3$ show the required power for flax and sunflower threshing respectively, the obtained data showed that the required power increased by increasing each of drum speed, and belt speed; where it decreased by 
increasing the concave clearance. The highest and the lowest values of the consumed power for flax crop of $6.14 \& 3.20 \mathrm{~kW}$ respectively were obtained at drum speed, belt speed, and concave clearance of $7.3 \& 4.2$ $\mathrm{m} / \mathrm{s}, 1.25 \& 0.42 \mathrm{~m} / \mathrm{s}$, and $1.5 \& 4.0 \mathrm{~cm}$ respectively. In addition, the highest and the lowest values of the consumed power of $6.58 \& 3.16 \mathrm{~kW}$ respectively were obtained with sunflower crop at $7.3 \& 4.2 \mathrm{~m} / \mathrm{s}$ of drum speed, $1.25 \& 0.42 \mathrm{~m} / \mathrm{s}$ of belt speed, and $2.5 \& 5.5 \mathrm{~cm}$ of concave clearance respectively.

Tables $4 \& 5$ showed that, the specific energy requirement $(\mathrm{kW} . \mathrm{h} / \mathrm{Mg})$ of flax threshing increased by increasing drum speed, and decreased by increasing each of belt speed and concave clearance. The manner was different something with sunflower, as the consumed energy increased by increasing drum speed and belt speed, while it decreased by increasing concave clearance. This difference is due to the difference in the increasing rate of the threshing machine productivity of both crops, i.e. with flax crop especially at high speeds of the belt, the hold on system is regulates the feeding rate more than the manual feeding with sunflower. Accordingly, machine productivity increasing rate with flax is higher than that with sunflower, so the energy decreased by increasing the belt speed with flax and increased with sunflower. The highest and the lowest values of the consumed energy of flax threshing of $10.73 \& 6.09$ $\mathrm{kW} . \mathrm{h} / \mathrm{Mg}$ were obtained at $7.3 \& 4.2 \mathrm{~m} / \mathrm{s}$ of drum speed, $0.42 \& 1.25 \mathrm{~m} / \mathrm{s}$ of belt speed, and $1.5 \& 4.0 \mathrm{~cm}$ of concave clearance respectively. In addition, the highest and the lowest values of the consumed energy in case of sunflower threshing were $17.01 \& 8.09 \mathrm{~kW} . \mathrm{h} / \mathrm{Mg}$ obtained at 7.3 $\& 4.2 \mathrm{~m} / \mathrm{s}$ of drum speed, $1.25 \& 0.42 \mathrm{~m} / \mathrm{s}$ of belt speed, and $2.5 \& 5.5$ $\mathrm{cm}$ of concave clearance respectively.

\section{6- Criterion Cost:}

The criterion cost $\mathrm{LE} / \mathrm{Mg}$ includes the total cost and the price of the lost and damaged seeds, and the price of the lost flax stalks. The data presented in Tables $6 \& 7$ cleared that the criterion cost values decreased by increasing drum speed. That is because of increasing the threshing machine productivity and decreasing the seed losses by increasing the drum speed. The results revealed also that, the criterion cost values for 
flax and sunflower increased by increasing belt speed and concave clearance. This attributed to increase the threshing losses by increasing each of belt speed and concave clearance. The lowest values of the criterion cost of flax and sunflower were $394.9 \& 158.5 \mathrm{LE} / \mathrm{Mg}$ respectively, which obtained at drum speed of $7.3 \mathrm{~m} / \mathrm{s}$, belt speed of 0.42 $\mathrm{m} / \mathrm{s}$, and concave clearances of $1.5 \& 2.5 \mathrm{~cm}$ respectively. In addition to, the highest values of the criterion cost of $637.1 \& 696.8 \mathrm{LE} / \mathrm{Mg}$ were obtained with flax and sunflower respectively, at $4.2 \mathrm{~m} / \mathrm{s}$ of drum speed, $1.25 \mathrm{~m} / \mathrm{s}$ of belt speed, $4.0 \& 5.5 \mathrm{~cm}$ of concave clearance respectively.

Table (2): Effect of drum speed, belt speed, and concave clearance on power requirement $(\mathrm{kW})$ of flax crop threshing

\begin{tabular}{|c|c|c|c|c|c|c|c|c|c|c|c|c|}
\hline \multirow{4}{*}{$\begin{array}{l}\text { Belt } \\
\text { speed, } \\
\text { m/s }\end{array}$} & \multicolumn{12}{|c|}{ Concave clearance, $\mathrm{cm}$} \\
\hline & \multicolumn{4}{|c|}{1.5} & \multicolumn{4}{|c|}{2.5} & \multicolumn{4}{|c|}{4.0} \\
\hline & \multicolumn{4}{|c|}{ Drum speed, $\mathbf{m} / \mathbf{s}$} & \multicolumn{4}{|c|}{ Drum speed, $\mathbf{m} / \mathbf{s}$} & \multicolumn{4}{|c|}{ Drum speed, $\mathrm{m} / \mathrm{s}$} \\
\hline & 4.2 & 5.5 & 6.4 & 7.3 & 4.2 & 5.5 & 6.4 & 7.3 & 4.2 & 5.5 & 6.4 & 7.3 \\
\hline 0.42 & 3.91 & 4.24 & 4.62 & 5.21 & 3.71 & 4.12 & 4.49 & 5.05 & 3.20 & 3.64 & 4.13 & 4.69 \\
\hline 0.67 & 4.22 & 4.58 & 5.07 & 5.62 & 3.88 & 4.31 & 4.73 & 5.25 & 3.60 & 4.02 & 4.42 & 5.11 \\
\hline 0.96 & 4.46 & 4.93 & 5.34 & 5.87 & 4.05 & 4.52 & 4.89 & 5.46 & 3.76 & 4.20 & 4.72 & 5.40 \\
\hline 1.25 & 4.77 & 5.16 & 5.62 & 6.14 & 4.24 & 4.66 & 5.12 & 5.61 & 3.92 & 4.40 & 4.83 & 5.56 \\
\hline
\end{tabular}

Table (3): Effect of drum speed, belt speed, and concave clearance on power requirement $(\mathrm{kW})$ of sunflower crop threshing

\begin{tabular}{|c|c|c|c|c|c|c|c|c|c|c|c|c|}
\hline \multirow{4}{*}{$\begin{array}{l}\text { Belt } \\
\text { speed, } \\
\text { m/s }\end{array}$} & \multicolumn{12}{|c|}{ Concave clearance, $\mathrm{cm}$} \\
\hline & \multicolumn{4}{|c|}{2.5} & \multicolumn{4}{|c|}{4.0} & \multicolumn{4}{|c|}{5.5} \\
\hline & \multicolumn{4}{|c|}{ Drum speed, $\mathrm{m} / \mathrm{s}$} & \multicolumn{4}{|c|}{ Drum speed, $\mathrm{m} / \mathrm{s}$} & \multicolumn{4}{|c|}{ Drum speed, $\mathbf{m} / \mathbf{s}$} \\
\hline & 4.2 & 5.5 & 6.4 & 7.3 & 4.2 & 5.5 & 6.4 & 7.3 & 4.2 & 5.5 & 6.4 & 7.3 \\
\hline 0.42 & 3.93 & 4.29 & 4.76 & 5.38 & 3.52 & 4.00 & 4.45 & 4.96 & 3.16 & 3.48 & 3.92 & 4.49 \\
\hline 0.67 & 4.22 & 4.72 & 5.12 & 5.66 & 3.82 & 4.31 & 4.55 & 5.21 & 3.27 & 3.71 & 4.28 & 4.81 \\
\hline 0.96 & 4.52 & 5.03 & 5.48 & 6.02 & 4.28 & 4.71 & 5.16 & 5.58 & 3.51 & 3.94 & 4.55 & 5.08 \\
\hline 1.25 & 4.86 & 5.37 & 5.94 & 6.58 & 4.47 & 4.87 & 5.41 & 5.94 & 3.88 & 4.25 & 4.83 & 5.51 \\
\hline
\end{tabular}


Table (4): Effect of drum speed, belt speed, and concave clearance on energy requirement $(\mathrm{kW} . \mathrm{h} / \mathrm{Mg})$ of flax crop threshing

\begin{tabular}{|c|c|c|c|c|c|c|c|c|c|c|c|c|}
\hline \multirow{4}{*}{\begin{tabular}{|l} 
Belt \\
speed, \\
m/s
\end{tabular}} & \multicolumn{12}{|c|}{ Concave clearance, $\mathrm{cm}$} \\
\hline & \multicolumn{4}{|c|}{1.5} & \multicolumn{4}{|c|}{2.5} & \multicolumn{4}{|c|}{4.0} \\
\hline & \multicolumn{4}{|c|}{ Drum speed, $\mathrm{m} / \mathrm{s}$} & \multicolumn{4}{|c|}{ Drum speed, $\mathrm{m} / \mathrm{s}$} & \multicolumn{4}{|c|}{ Drum speed, $\mathbf{m} / \mathbf{s}$} \\
\hline & 4.2 & 5.5 & 6.4 & 7.3 & 4.2 & 5.5 & 6.4 & 7.3 & 4.2 & 5.5 & 6.4 & 7.3 \\
\hline 0.42 & 9.96 & 10.11 & 10.28 & 10.73 & 8.13 & 8.24 & 8.43 & 8.89 & 6.37 & 6.63 & 6.87 & 7.33 \\
\hline 0.67 & 9.89 & 10.04 & 10.23 & 10.65 & 7.76 & 8.07 & 8.26 & 8.68 & 6.24 & 6.47 & 6.74 & 7.29 \\
\hline 0.96 & 9.70 & 9.91 & 10.08 & 10.45 & 7.74 & 7.95 & 8.15 & 8.57 & 6.16 & 6.39 & 6.67 & 7.24 \\
\hline 1.25 & 9.52 & 9.73 & 9.90 & 10.26 & 7.61 & 7.85 & 8.05 & 8.45 & 6.09 & 6.26 & 6.55 & 7.09 \\
\hline
\end{tabular}

Table (5): Effect of drum speed, belt speed, and concave clearance on energy requirement $(\mathrm{kW} . \mathrm{h} / \mathrm{Mg})$ of sunflower crop threshing

\begin{tabular}{|c|c|c|c|c|c|c|c|c|c|c|c|c|}
\hline \multirow{4}{*}{\begin{tabular}{|l|} 
Belt \\
speed, \\
m/s
\end{tabular}} & \multicolumn{12}{|c|}{ Concave clearance, $\mathrm{cm}$} \\
\hline & \multicolumn{4}{|c|}{2.5} & \multicolumn{4}{|c|}{4.0} & \multicolumn{4}{|c|}{5.5} \\
\hline & \multicolumn{4}{|c|}{ Drum speed, $\mathrm{m} / \mathrm{s}$} & \multicolumn{4}{|c|}{ Drum speed, $\mathrm{m} / \mathrm{s}$} & \multicolumn{4}{|c|}{ Drum speed, $\mathrm{m} / \mathrm{s}$} \\
\hline & 4.2 & 5.5 & 6.4 & 7.3 & 4.2 & 5.5 & 6.4 & 7.3 & 4.2 & 5.5 & 6.4 & 7.3 \\
\hline 0.42 & 12.32 & 12.71 & 13.38 & 14.52 & 9.93 & 10.76 & 11.65 & 12.41 & 8.09 & 8.46 & 9.13 & 10.07 \\
\hline 0.67 & 12.89 & 13.73 & 14.26 & 15.07 & 10.65 & 11.61 & 11.91 & 12.90 & 8.36 & 9.05 & 9.85 & 10.75 \\
\hline 0.96 & 13.54 & 14.28 & 15.17 & 15.97 & 11.68 & 12.24 & 13.04 & 13.46 & 8.85 & 9.43 & 10.44 & 11.12 \\
\hline 1.25 & 14.26 & 15.06 & 16.26 & 17.01 & 12.11 & 12.66 & 13.57 & 14.14 & 9.62 & 10.07 & 11.05 & 12.02 \\
\hline
\end{tabular}

Table (6): Effect of drum speed, belt speed, and concave clearance on criterion cost (LE/Mg) of flax crop threshing

\begin{tabular}{|c|c|c|c|c|c|c|c|c|c|c|c|c|}
\hline \multirow{4}{*}{$\begin{array}{l}\text { Belt } \\
\text { speed, } \\
\mathrm{m} / \mathrm{s}\end{array}$} & \multicolumn{12}{|c|}{ Concave clearance, $\mathrm{cm}$} \\
\hline & \multicolumn{4}{|c|}{1.5} & \multicolumn{4}{|c|}{2.5} & \multicolumn{4}{|c|}{4.0} \\
\hline & \multicolumn{4}{|c|}{ Drum speed, $\mathbf{m} / \mathbf{s}$} & \multicolumn{4}{|c|}{ Drum speed, $\mathrm{m} / \mathrm{s}$} & \multicolumn{4}{|c|}{ Drum speed, $\mathbf{m} / \mathbf{s}$} \\
\hline & 4.2 & 5.5 & 6.4 & 7.3 & 4.2 & 5.5 & 6.4 & 7.3 & 4.2 & 5.5 & 6.4 & 7.3 \\
\hline 0.42 & 515.1 & \begin{tabular}{|l|}
474.4 \\
\end{tabular} & 419.3 & 394.9 & 550.2 & 493.0 & 455.6 & 409.5 & 593.1 & 532.3 & 471.6 & 441.2 \\
\hline 0.67 & 507.8 & 467.2 & 422.1 & 398.5 & 531.2 & 476.4 & 445.0 & 421.1 & 602.0 & 524.7 & 478.1 & 430.9 \\
\hline 0.96 & 530.1 & 485.0 & 441.4 & 410.3 & 553.1 & 502.2 & 466.7 & 439.5 & 603.2 & 549.4 & 495.0 & 457.7 \\
\hline 1.25 & 542.3 & 503.3 & 435.7 & 403.5 & 580.9 & 526.1 & 497.2 & 467.2 & 637.1 & 581.4 & 518.1 & 482.7 \\
\hline
\end{tabular}

Table (7): Effect of drum speed, belt speed, and concave clearance on criterion cost $(\mathrm{LE} / \mathrm{Mg})$ of sunflower crop threshing

\begin{tabular}{|c|c|c|c|c|c|c|c|c|c|c|c|c|}
\hline \multirow{4}{*}{$\begin{array}{l}\text { Belt } \\
\text { speed, } \\
\text { m/s }\end{array}$} & \multicolumn{12}{|c|}{ Concave clearance, $\mathrm{cm}$} \\
\hline & \multicolumn{4}{|c|}{2.5} & \multicolumn{4}{|c|}{4.0} & \multicolumn{4}{|c|}{5.5} \\
\hline & \multicolumn{4}{|c|}{ Drum speed, $\mathbf{m} / \mathbf{s}$} & \multicolumn{4}{|c|}{ Drum speed, $\mathbf{m} / \mathbf{s}$} & \multicolumn{4}{|c|}{ Drum speed, $\mathrm{m} / \mathrm{s}$} \\
\hline & 4.2 & 5.5 & 6.4 & 7.3 & 4.2 & 5.5 & 6.4 & 7.3 & 4.2 & 5.5 & 6.4 & 7.3 \\
\hline 0.42 & 347.5 & 272.6 & 214.8 & 158.5 & 441.7 & 366.3 & 315.3 & 239.9 & $\mathbf{5 8 7 . 0}$ & 478.3 & 381.1 & 304.8 \\
\hline 0.67 & 368.9 & 288.3 & 230.9 & 169.1 & 467.8 & 420.2 & $\mathbf{3 3 7 . 9}$ & 267.0 & 623.5 & 512.7 & 372.2 & $\mathbf{3 2 3 . 0}$ \\
\hline 0.96 & 391.2 & 314.2 & 269.3 & 211.8 & 539.1 & 431.5 & 392.4 & 293.3 & 650.1 & 543.7 & 449.9 & 348.6 \\
\hline 1.25 & 416.7 & 343.8 & 313.8 & 237.5 & 569.1 & 487.6 & 425.8 & 313.3 & 696.8 & 599.4 & 531.1 & 419.1 \\
\hline
\end{tabular}




\section{CONCLUSION}

The aim of this study is to develop a rubbing thresher suiting for seed crops, and evaluate the developed thresher on threshing two crops namely flax and sunflower crops. The developed thresher was tested at four levels of drum speed of 4.2, 5.5, 6.4 , and $7.3 \mathrm{~m} / \mathrm{s}$, four levels of belt speed of $0.42,0.67,0.96$, and $1.25 \mathrm{~m} / \mathrm{s}$, and three levels of concave clearance for each crop of 1.5, 2.5, $4.0 \mathrm{~cm}$ with flax crop; and 2.5, 4.0, $5.5 \mathrm{~cm}$ with sunflower. From the obtained data, it can be concluded the following:-

1- For the two crops, increasing drum speed increased the threshing efficiency, flax stalk losses, visible seed damage, machine productivity, required power, consumed specific energy, and decreased the criterion cost.

2- Increasing the belt speed decreased the threshing efficiency of the two crops, decreased the flax stalk losses, decreased the visible seed damage of sunflower, and decreased the consumed energy with flax threshing. Whereas, increasing the belt speed increased the threshing machine productivity of the two crops, increased the required power, increased the consumed energy with sunflower, and increased the criterion cost of threshing the two crops.

3- For the two crops, increasing the concave clearance decreased the threshing efficiency, the flax stalk losses, the visible seed damage, the required power, and consumed energy. While, the machine productivity and the criterion cost were increased by increasing the concave clearance.

4- Neither visible nor invisible seed damage was occurred with flax crop, and from the obtained results we found that:-

The optimum conditions for threshing flax crop by the modified thresher are drum speed about $7.3 \mathrm{~m} / \mathrm{s}$, belt speed about $0.42 \mathrm{~m} / \mathrm{s}$, and concave clearance about $1.5 \mathrm{~cm}$. Whereas, The optimum conditions for threshing sunflower crop by the modified thresher are drum speed about $7.3 \mathrm{~m} / \mathrm{s}$, belt speed about $0 . .42 \mathrm{~m} / \mathrm{s}$, and concave clearance about $2.5 \mathrm{~cm}$

\section{REFERENCES}

Bainer, R.; R.A. Kepner and E.L. Barger (1982). Principles of farm machinery. Willey and Sons Inc. New York. 
El-Ashry, A.S. (2011). Design and construction of a flax rubbing deseeder. Misr J. of Agr. Eng., 28(2): 250-265.

El-Ashry, A.S.; O.A. Omar and E.H. Musa (2006). Improvement of tractor performance in respect of increasing threshing efficiency of flax crop. Misr J. of Agr. Eng., 23(3): 532-548.

Kepner, R.A.; R. Bainer and L.E. Barger (1982). Principle of farm machinery, The AVI Pub. Comp. INC, Westport conn.

Khater, A.E.A. (2000). Mechanization of sunflower threshing. M.Sc. thesis Agr. Mech. Dept. Fac. of Agr. Mansoura Univ. pp: 86.

Klenin, H.I.; I.F. Popover and V.A. Sakum (1985). Agriculture machines. American publishing. Pvt. LT D. New York.

Lockwood, F.B. and R. Dunstan (1971). Electrical engineering principles. Meinemann Educational Books. Ltd. London.

Mesquita, C.M. and M.A. Hanna (1993). Soybean threshing mechanics: I Frictional rubbing by flat belts. Transactions of ASAE, 36 (2): 275279.

Schild, J.; P. Baltensperger; P. Lyon; G. Hein and E. Kerr (1991). Sunflower production in Nebraska. G 91 -1026- A: 1-7.

Sudajan, S.; V.M. Salokhe and K. Triratanasirichai (2002). Effect of type of drum, drum speed and feed rate on sunflower threshing. Biosystems Eng. J. 83 (4): 413-421

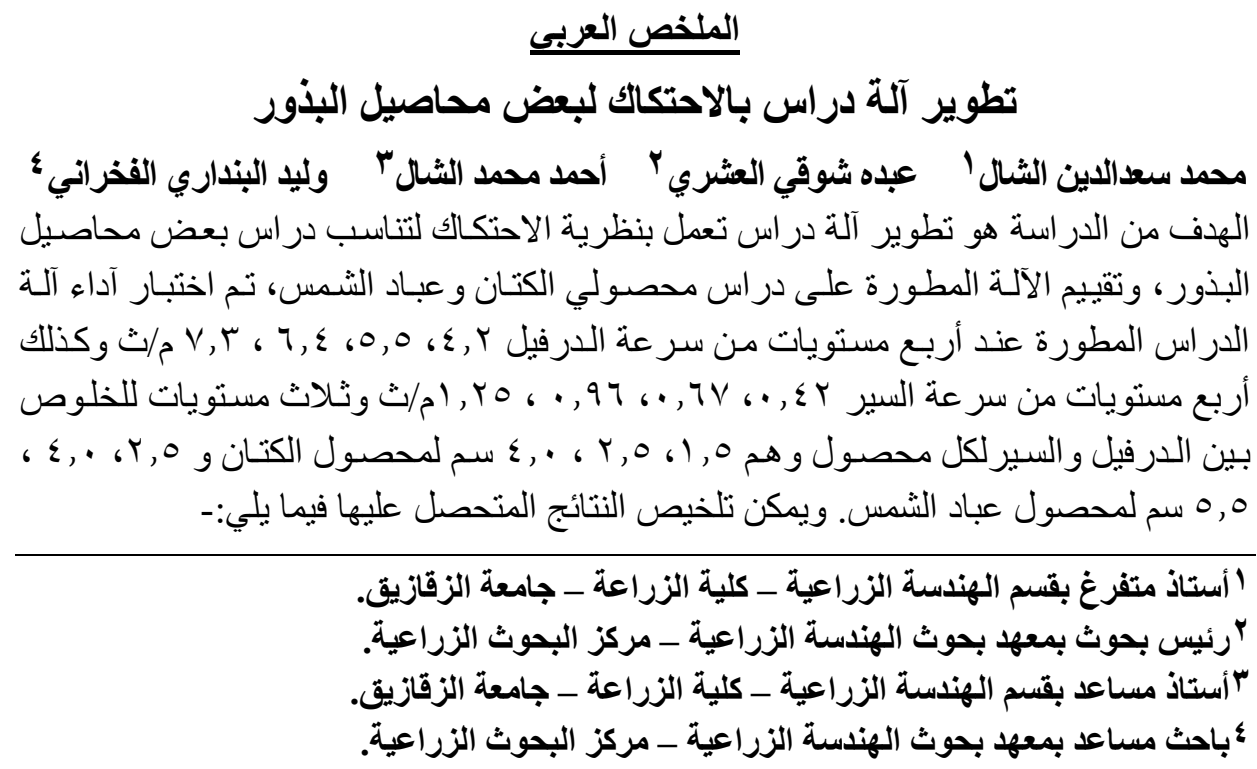


ا-زيادة سرعة الدرفيل أثناء در اس كل من المحصولين أدى إلى زيادة كل من:- كفاءة الدر اس،

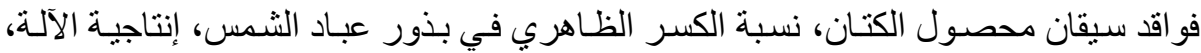

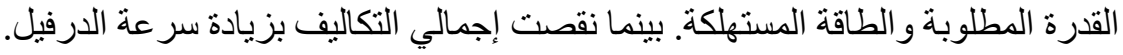
r-زيادة سر عة السير أدى إلى نقص كل من:- كفاءة الدر اس لكل من المحصـولين، فو اقد سيقان

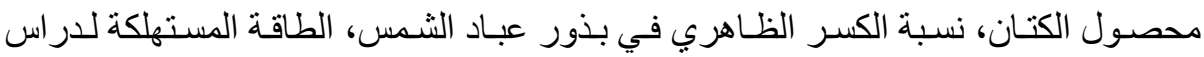

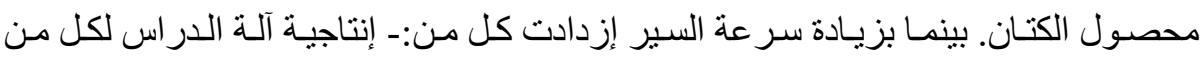

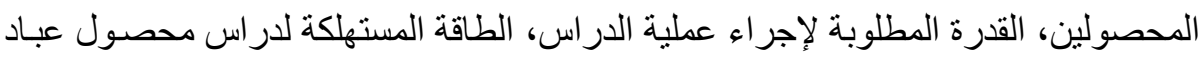
الشمس، وكذلك إجمالي التكاليف. ب-زيادة الخلوص بين درفيل الدر اس و السير أثناء در اس كل من المحصولين أدى إلى نقص كل

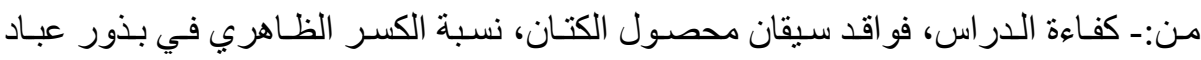

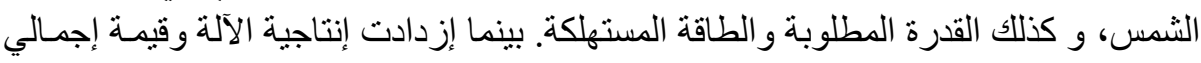
التكاليف بزيادة الخلوص بين درفيل الدر اس و السير. ع ـلم يظهر أي كسر ظاهري أو غير ظاهري في بذور محصدول الكتان. ومن النتائج المتحصل

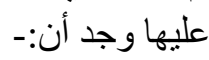
أفضل ظروف التشـيل المناسبة لدر اس محصول الكتان باستخدام آلة الدر اس المطورة هي:-

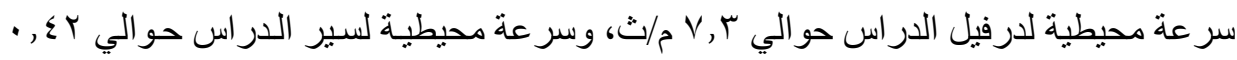

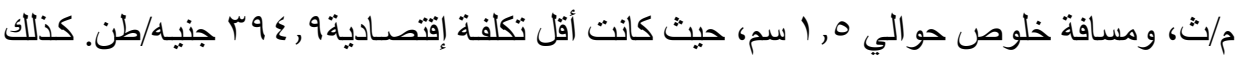
أفضل ظروف التشغيل المناسبة لدر اس محصول عبـاد الثمس باستخدام آلة الدر اس المطورة

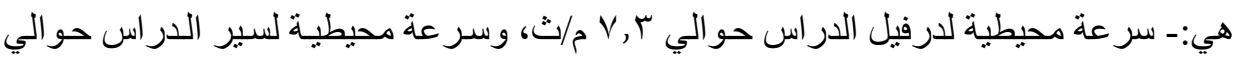

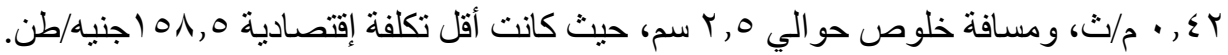

